DOI: https://doi.org/10.47405/mjssh.v6i2.673

\begin{tabular}{|c|c|}
\hline 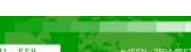 & Malaysian Journal of Social Sciences and Humanities (MJSSH) \\
\hline Malaysian Journa of & Volume 6, Issue 2, February 2021 \\
\hline (MJ-SSH) & e-ISSN : 2504-8562 \\
\hline & $\begin{array}{l}\text { Journal home page: } \\
\text { www.msocialsciences.com }\end{array}$ \\
\hline
\end{tabular}

\title{
Living Heritage Village of Kampung Morten Melaka: Local Community Involvement in Tourism
}

\author{
Syakir Amir Ab Rahman1', Wan Amerul Akhyar Mohd Fauzi' ${ }^{1}$, Syahriah Bachok ${ }^{1}$, M.Zainora Asmawi1, \\ Zakiah Ponrahano ${ }^{2}$, Nur Aulia Rosni ${ }^{3}$, Yukihiro Masuda ${ }^{4}$, Nadiah Najib ${ }^{5}$ \\ ${ }^{1}$ Department of Urban and Regional Planning, Kulliyyah of Architecture and Environmental Design, International \\ Islamic University Malaysia \\ ${ }^{2}$ Department of Environment, Faculty of Forestry and Environment, Universiti Putra Malaysia \\ ${ }^{3}$ Centre of Sustainable Urban Planning and Real Estate, Faculty of Built Environment, Universiti Malaya \\ ${ }^{4}$ Department of Planning, Architecture and Environmental System, Shibaura Insitute of Technology \\ 5PLANMalaysia
}

Correspondence: Syakir Amir Ab Rahman (syakiramir@iium.edu.my)

\begin{abstract}
Community-based Tourism (CBT) involves high community participation at the highest level of decision-making processes, to economic involvement and the giving opinion of the lowest level goal. The purpose of this study is to explore the local community participation in the tourism activities in Kampung Morten, Melaka. The questionnaire survey was conducted using a simple random sampling method among 152 respondents and the results were analysed using crosstabulation analysis. The main findings are the majority of respondents participated in tourism activities and deliberation in tourism activities. Less number of respondents were giving opinions on tourism development and plans. This study is benefitable to the tourism stakeholders to ensure the relevancy of communities staying in living heritage villages to contribute to the domestic tourism industry.
\end{abstract}

Keywords: community-based tourism, local participation, local community, Kampung Morten

\section{Introduction}

Community Based Tourism (CBT) was introduced as a new tourism product in $7^{\text {th }}$ Malaysia Plan (19962000) after the start of the homestay tourism in Malaysia. CBT is a tourism product which foremost part of the management is managed by local communities (Satarat, 2010). Local communities are given fully trusted to manage their tourism management starting from decision making, planning, evaluation and control of the tourism management. Before the introduction of CBT, the homestay operator did not follow the guidelines. They operate the homestay for their own benefits without giving effects towards the local communities (Kaur et al., 2014). CBT empowers the local communities in every aspect of tourism management in their communities and to emphasize the environmental, social and cultural sustainability (Osman et. al., 2008; 2010). The advantage of CBT is that it is managed and owned by the community for the community. Moreover, CBT provides tourists with the opportunity of learning about the community's lifestyle, local culture and customs (Mapjabil et. al., 2011). With this, local communities and tourists will be exposed towards cultural heritage, social reliability and natural environment. It can enhance the community's socio-economic development through the income generated from their participation in the homestay programmes (Chaiyatorn et al., 2010). 
The communities nowadays more focus on benefits on themselves rather than to the local communities itself. This type of awareness will neglect the successful in product of tourism which affect the community's socio-economic itself. To gain the best output from the CBT product, there must be increase in awareness among local communities to participate in tourism activities. For such situation happen, CBT needs to be enhanced in its effectiveness to the local communities over time. Local Communities need to be totally empowered in tourism management within their communities for them to independently grow in which homestay is an integral part in CBT (Kaur et al., 2016). The government and recognized agencies have to play an important role with the local communities because the main agenda of CBT besides improving the life of the local communities, are also to preserve the social, cultural and environment of the local communities. The aims of this paper is to identify the segmentation of local communities in Kampung Morten that participate in tourism activities and involve in planning the tourism plans in Melaka.

\section{Literature Review}

Community-based tourism is one of the tourism approaches in the platform of sustainability. It is emerged to avoid over usage of resources that may affect the environment, and focuses the local community well-being (Lepp, 2007; Dodds et al., 2018). It is recognizes the importance of social dimension. O'neil (2008) defines CBT as 'a situation in which local people, usually those that are poor or economically marginalized in very rural parts of the world, open up their homes and communities to visitors seeking sustainably achieved cultural, educational or recreational travel experiences'. The idea behind the community-based approach is to create potential for empowering the community, enhancing their involvement in decision making, and making sure that the will and incentive to participate come from the community itself (Armstrong et al, 2003). It is given emphasized on the social dimension while recognized the economic and environmental sustainability. CBT can not only help local villagers control the impacts of tourism, but also generate additional incomes and diversify the local economy (Tuffin, 2005). Furthermore, with the money gained from CBT, the health and education of local people can also be improved, which can go further to alleviate poverty, decrease population growth and solve land distribution problems (Murdoch, 1980 quoted in Lash, 1998).

CBT allows the local community to control over and is involved in, its development and management and the major contribution remain among the community (Wang et al., 2016). It shows that CBT activities are developed and operated, for the most part, by local community members, and certainly with their consent and support. It utilizes a wide range of resources that local people are able to manage and particularly involves respect for local culture, heritage, and traditions (Leksakundilok, 2004). Local people must be able to control and manage productive resources in the interests of their own families and the community. Therefore, it is also important that a reasonable proportion of tourism revenues are enjoyed by the community in one way or another.

CBT enablers the visitors to increase their awareness and learn about the community and local ways of life (Choi \& Sirakaya, 2006). Preserving local culture is also another benefit of CBT. If communities know the value of their traditions and culture, then wisdom and local knowledge can be transferred from generation to generation. In addition, cooperation with government and private agencies, close contact with tourists and improving quality of life are also social benefits from CBT. The social cohesion, harmony and cooperation that CBT enables can enhance individual self-reliance, pride and hope for the future as well (Ross \& Wall, 1999 quoted in Kontogeorgopoulos, 2005).

Several researchers have segmented CBT into several components. (1) CBT must contribute to increasing and/or improving conservation of natural and/or cultural resources (Choi \& Sirakaya, 2006) (2) CBT must contribute to local economic development through increasing tourism revenues and other benefits to community participants, and ideally to an increasing number of participants (Dieddrich \& Garcia, 2009; Woo et al., 2015); (3) CBT must have a level of participation, ideally progressing toward self-mobilization, but not always necessary (Lepp, 2007); and (4) CBT has to provide a socially and 
environmentally responsible product to the visitors (Gurung \& Seeland, 2008). In short, it is important to note that the objectives of CBT are not always focused on natural conservation and economic prosperity. Cultural preservation, community empowerment, poverty alleviation, and income generation are also significant goals. CBT much associated with community participation in any tourism process including planning (Ahn et al., 2002; Lee et al, 2013), contribution (Lee et al., 2013), involvement (Choi $\&$ Sirakaya, 2006) and benefits (Yoon et al., 2016)

\section{Kampung Morten}

Kampung Morten was chosen as the study area. It is located in Melaka City and adjacent to Melaka river. Kampung Morten is a historical traditional Malay village in which surrounded by Melaka River. Though it is being surrounded by massive development and variety of tourism activities, Kampung Morten has succeeded in retaining their traditional elements and living. According to Amir et al, (2020), Kampung Morten has grown into a centre for Melaka's tourism activities since 1989, when it was designated a heritage village under the state's Preservation and Conservation Enactment in 1989. Table 1 below provides a description of Kampung Morten site profile.

Table 1: Summary Background of Kampung Morten

\begin{tabular}{lc}
\hline \multicolumn{1}{c}{ Items } & Kampung Morten \\
\hline Area (acres) & 12.4 \\
Population & 900 \\
Country & Malaysia \\
Prefecture/State & Melaka \\
Year built & 1921 \\
No. of houses & 90 traditional houses \\
UNESCO recognition & July 2008 \\
\hline
\end{tabular}

\section{Methodology}

The population of Kampung Morten is approximately 900 people, with 90 traditional houses on the 5 hectare land (Amir et al, 2020). Therefore, the sample consisted of 152 based on sampling size table by Krejcie \& Morgan (1970). Purposive sampling technique was selected as the sampling method. The questionnaire survey was distributed in each house. Two categories of respondents were participated, namely head of family and family representatives. The date that consists of respondents segmentations of social demographics with three types of community participations were plotted and analysed with crosstabulation analysis. The three categories of community participations in Communitybased Tourism are based on literature reviews: 1) Participation in tourism activities (Asker et al., 2010;), 2) Participation in giving opinions (Castro \& Nielsen, 2002; Sheppard \& Metiner, 2005; Dredge, 2010), 3) Participation in deliberation (Marshall et al., 2007; Beaumont \& Dredge, 2009)

\section{Result}

Below are the crosstabulation test results on community participation in tourism activities as well as community involvment in giving opinions and views on tourism plans in Melaka.

\section{Community Participation in Tourism Activities}

Table 1 indicates community participation in several tourism sectors and activities, namely food and beverage, accommodation, transportation, retail, recreation, culture and other related tourism activities. 27 respondents who work in freelance involved directly in food and beverage sectors followed by 16 
DOI: https://doi.org/10.47405/mjssh.v6i2.673

freelancer work in accommodation sector. 10 respondents who work in the private sector involved in transportation. 4 respondents work in government sector work in retail activities. 2 respondents from private sector involve in recreation activities while 4 respondents work in government sector. However, almost 40\% (57) respondents in Kampung Morten did not involve in any tourism activities in Melaka.

Table 1: Crosstabulation Test: Community Participation in Tourism Activities and Employment

\begin{tabular}{cccccc}
\hline & & \multicolumn{3}{c}{ Employment } & Total \\
\cline { 3 - 5 } & Food and beverage & 0 & 1 & 27 & $\mathbf{2 8}$ \\
& Accommodation & 2 & 8 & 16 & $\mathbf{2 6}$ \\
Participation in & Transportation & 7 & 10 & 6 & $\mathbf{2 3}$ \\
Tourism Activities & Retail & 4 & 2 & 2 & $\mathbf{8}$ \\
& Recreation & 1 & 2 & 0 & $\mathbf{3}$ \\
& Culture & 4 & 1 & 0 & $\mathbf{5}$ \\
& Others & 1 & 0 & 1 & $\mathbf{2}$ \\
\hline & No participation & 8 & 40 & 9 & $\mathbf{5 7}$ \\
\hline
\end{tabular}

Table 2 indicates community participation based on their qualification of education. Majority of the community who have SPM qualifications involved in all tourism sectors with 12 of them in food and beverage sector, 10 in accommodation sector, 12 in transportation sector, 3 in culture, 2 each in retail sector and recreation. In addition, 18 respondents who do not have qualifications also actively involved in tourism activities.

Table 2: Crosstabulation Test: Community Participation in Tourism Activities and Education

\begin{tabular}{|c|c|c|c|c|c|c|c|c|}
\hline & \multicolumn{6}{|c|}{ Education } & \multirow[b]{2}{*}{ Total } \\
\hline & & SPM & $\begin{array}{l}\text { STPM/ } \\
\text { Matric. }\end{array}$ & Cert. & Diploma & Bachelor & $\begin{array}{c}\text { No } \\
\text { qualificatio } \\
n\end{array}$ & \\
\hline \multirow{9}{*}{$\begin{array}{c}\text { Participatio } \\
\text { n in } \\
\text { Tourism } \\
\text { Activities }\end{array}$} & $\begin{array}{l}\text { Food and } \\
\text { beverage }\end{array}$ & 12 & 0 & 0 & 6 & 0 & 10 & 28 \\
\hline & Accommodation & 10 & 0 & 1 & 12 & 0 & 3 & 26 \\
\hline & Transportation & 12 & 0 & 6 & 0 & 3 & 2 & 23 \\
\hline & Retail & 2 & 0 & 0 & 0 & 4 & 2 & 8 \\
\hline & Recreation & 2 & 1 & 0 & 0 & 0 & 0 & 3 \\
\hline & Culture & 3 & 2 & 0 & 0 & 0 & 0 & 5 \\
\hline & Others & 0 & 1 & 0 & 0 & 0 & 1 & 2 \\
\hline & No participation & 29 & 1 & 1 & 2 & 1 & 23 & 57 \\
\hline & Total & 70 & 5 & 8 & 20 & 8 & 41 & 152 \\
\hline
\end{tabular}

Table 3 indicates the community participation in tourism activities based on age groups. Firstly, majority of the local community who are 41 years and above actively participated in tourism sectors. Secondly, 11 respondents who are below 30 years old involve in transportation activities. Surpisingly, there are 13 respondents who are above 61 years old still actively involve in tourism activities in Melaka.

Table 3: Crosstabulation Test: Community Participation in Tourism Activities and Age

\begin{tabular}{lcccccccc}
\hline & $\mathbf{1 1 - 2 0}$ & $\mathbf{2 1 - 3 0}$ & $\mathbf{3 1 - 4 0}$ & $\mathbf{4 1 - 5 0}$ & $\mathbf{5 1 - 6 0}$ & Above 61 & Total \\
$\begin{array}{c}\text { Food and } \\
\text { beverage }\end{array}$ & $\mathbf{1}$ & $\mathbf{4}$ & $\mathbf{6}$ & $\mathbf{8}$ & $\mathbf{7}$ & $\mathbf{2}$ & $\mathbf{2 8}$ \\
\hline Accommodation & 0 & 3 & 3 & 11 & 5 & 4 & 26 \\
\hline
\end{tabular}


DOI: https://doi.org/10.47405/mjssh.v6i2.673

\begin{tabular}{ccccccccc}
\hline $\begin{array}{c}\text { Participatio } \\
\mathbf{n} \text { in } \\
\begin{array}{c}\text { Tourism } \\
\text { Activities }\end{array}\end{array}$ & $\begin{array}{c}\text { Transportation } \\
\text { Retail }\end{array}$ & 0 & 11 & 0 & 3 & 8 & 1 & $\mathbf{2 3}$ \\
& Recreation & 0 & 1 & 1 & 0 & 0 & 1 & $\mathbf{3}$ \\
& Culture & 0 & 1 & 1 & 0 & 1 & 2 & $\mathbf{5}$ \\
& Others & 1 & 0 & 0 & 1 & 0 & 0 & $\mathbf{2}$ \\
& No participation & 2 & 23 & 22 & 4 & 4 & 2 & $\mathbf{5 7}$ \\
\hline Total & $\mathbf{2 7}$ & $\mathbf{4}$ & $\mathbf{4 4}$ & $\mathbf{3 5}$ & $\mathbf{2 8}$ & $\mathbf{2 6}$ & $\mathbf{1 5}$ \\
\hline
\end{tabular}

\section{Community Participation in Giving Opinions}

Table 4 presents the frequency of local community give opinions on tourism plans based on employment. The record shows that only 55 respondents take the initiatives to participate in sharing views and opinion to any tourism plans and strategies. Surprisingly, 97 respondents did not participate in planning the tourism plans in Melaka. Moreover, respondents that work as freelancer are regularly active in sharing opinions with 29 respondents.

Table 4: Crosstabulation Test: Community Sharing Opinions in Tourism Plans and Employment

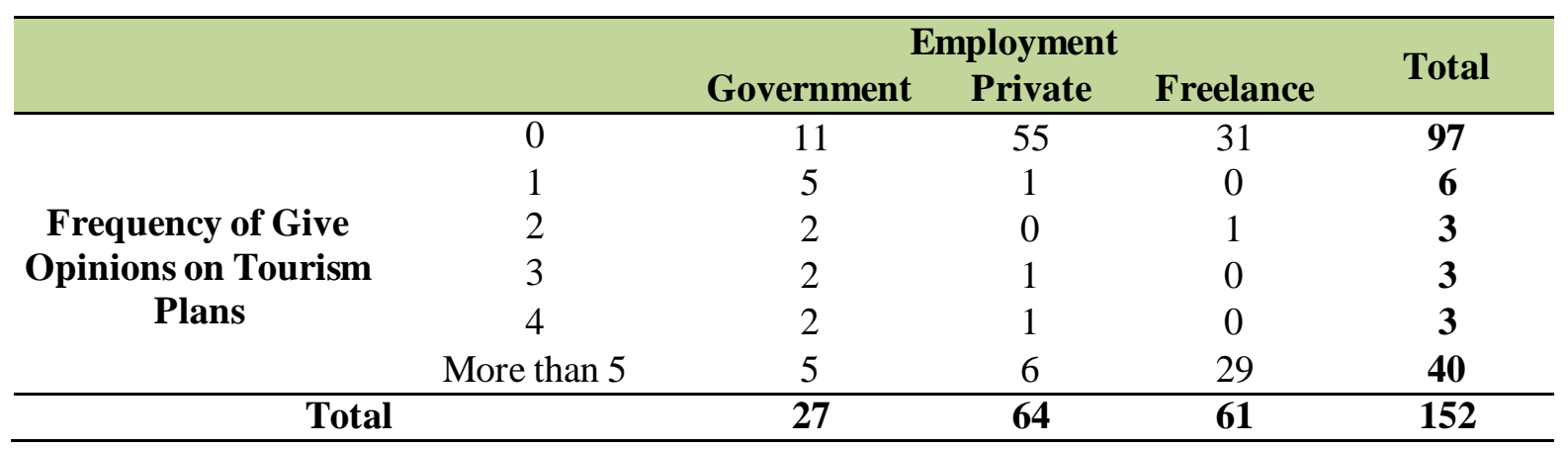

Table 5 indicates the community sharing opinions in tourism plans based on age groups. It clearly shows that most of the youth (30 years and below) have no interest in participating the tourism planning. Most of adults who are more than 41 years old regularly participated in giving opinions in tourism plans.

Table 5: Crosstabulation Test: Community Sharing Opinions in Tourism Plans and Age

\begin{tabular}{ccccccccc}
\hline & & $\mathbf{1 1 - 2 0}$ & $\mathbf{2 1 - 3 0}$ & $\mathbf{3 1 - 4 0}$ & $\mathbf{4 1 - 5 0}$ & $\mathbf{5 1 - 6 0}$ & Above 61 & Total \\
\hline \multirow{3}{*}{$\begin{array}{c}\text { Frequency } \\
\text { of Give }\end{array}$} & 0 & 3 & 40 & 26 & 11 & 11 & 6 & $\mathbf{9 7}$ \\
$\begin{array}{c}\text { Opinions on } \\
\text { Tourism }\end{array}$ & 1 & 0 & 1 & 1 & 0 & 2 & 2 & $\mathbf{6}$ \\
& 2 & 0 & 0 & 1 & 0 & 0 & 2 & $\mathbf{3}$ \\
& 4 & 0 & 1 & 0 & 0 & 0 & 2 & $\mathbf{3}$ \\
\multicolumn{2}{c}{ Total } & 1 & 0 & 0 & 0 & 1 & 1 & $\mathbf{3}$ \\
\hline
\end{tabular}

Table 6 above indicates the community sharing opinions in tourism plans based on education levels. Surprisingly, almost 10 respondents who have no proper qualifications have the initiatives to sharing opinions and views pertaining to the tourism plans in Melaka. Unfortunately, 31 respondents who have bachelor degree have no interest to participate. 
Table 6: Crosstabulation Test: Community Sharing Opinions in Tourism Plans and Education

\begin{tabular}{|c|c|c|c|c|c|c|c|c|}
\hline & & & & & lucation & & & \\
\hline & & SPM & $\begin{array}{l}\text { STPM/ } \\
\text { Matric. }\end{array}$ & Cert. & Diploma & Bachelo & $\begin{array}{c}\text { No } \\
\text { [ualificati } \\
\text { on }\end{array}$ & Total \\
\hline & 0 & 60 & 1 & 2 & 2 & 31 & 6 & 97 \\
\hline Frequency & 1 & 2 & 0 & 0 & 4 & 0 & 2 & 6 \\
\hline of Give & 2 & 1 & 0 & 0 & 2 & 0 & 2 & 3 \\
\hline Opinions & 3 & 0 & 1 & 0 & 0 & 0 & 2 & 3 \\
\hline on Tourism & 4 & 1 & 0 & 0 & 0 & 0 & 1 & $\mathbf{3}$ \\
\hline & More than 5 & 6 & 6 & 18 & 0 & 10 & 2 & 40 \\
\hline & tal & 70 & 8 & 20 & 8 & 41 & 15 & 152 \\
\hline
\end{tabular}

\section{Community Participation in Deliberation}

Table 7 shows the community participation in deliberation based on employment categories. The record shows that almost quarter of the total respondents did not participate in the deliberation of tourism activities in Melaka. 52 respondents have involve more than 5 times in the deliberation. However, most of the private employee in Kampung Morten have no interest.

Table 7: Crosstabulation Test: Frequency of Participation in Deliberation and Employment

\begin{tabular}{cccccc}
\hline & & \multicolumn{3}{c}{ Employment } & \multirow{2}{*}{ Total } \\
\cline { 3 - 5 } & 0 & Government & Private & Freelance & \\
\hline \multirow{3}{*}{ Frequency of } & 1 & 3 & 34 & 16 & $\mathbf{5 8}$ \\
Participation in & 2 & 7 & 2 & 4 & $\mathbf{9}$ \\
Deliberation & 3 & 2 & 1 & 1 & $\mathbf{9}$ \\
& 4 & 6 & 1 & 12 & $\mathbf{1 5}$ \\
& 5 & 0 & 2 & 1 & $\mathbf{7}$ \\
\hline Total & More than 5 & 1 & 24 & 27 & $\mathbf{5 2}$ \\
\hline
\end{tabular}

Table 8 indicates the community deliberation with age categories. Out of 52 respondents who involve more that 5 times in deliberation, more than half were the young adult (between 21-40 years old). Surprisingly, 35 respondents from these age categories were also did not participate in the deliberation.

Table 8: Crosstabulation Test: Frequency of Participation in Deliberation and Age

\begin{tabular}{cccccccccc}
\hline & & & $\mathbf{1 1 - 2 0}$ & $\mathbf{2 1 - 3 0}$ & $\mathbf{3 1 - 4 0}$ & $\mathbf{4 1 - 5 0}$ & $\mathbf{5 1 - 6 0}$ & Above 61 & Total \\
\hline \multirow{3}{*}{$\begin{array}{c}\text { Frequency of } \\
\text { Participation }\end{array}$} & 0 & 3 & 23 & 12 & 8 & 8 & 4 & $\mathbf{5 8}$ \\
in & 1 & 0 & 1 & 2 & 0 & 6 & 0 & $\mathbf{9}$ \\
Deliberation & 2 & 0 & 0 & 1 & 1 & 4 & 3 & $\mathbf{9}$ \\
& 3 & 0 & 2 & 2 & 8 & 3 & 0 & $\mathbf{1 5}$ \\
& 5 & 1 & 1 & 0 & 1 & 0 & 4 & $\mathbf{7}$ \\
\hline \multicolumn{2}{c}{ Total } & 5 & 0 & 0 & 0 & 1 & 1 & 0 & $\mathbf{2}$ \\
\hline
\end{tabular}

Table 9 shows the community deliberation with education level. 52 respondents with SPM qualification has no interest participating in deliberation. Surpisingly, 36 respondents with no qualifications participated in more than 5 times. 
Table 9: Crosstabulation Test: Frequency of Participation in Deliberation and Education

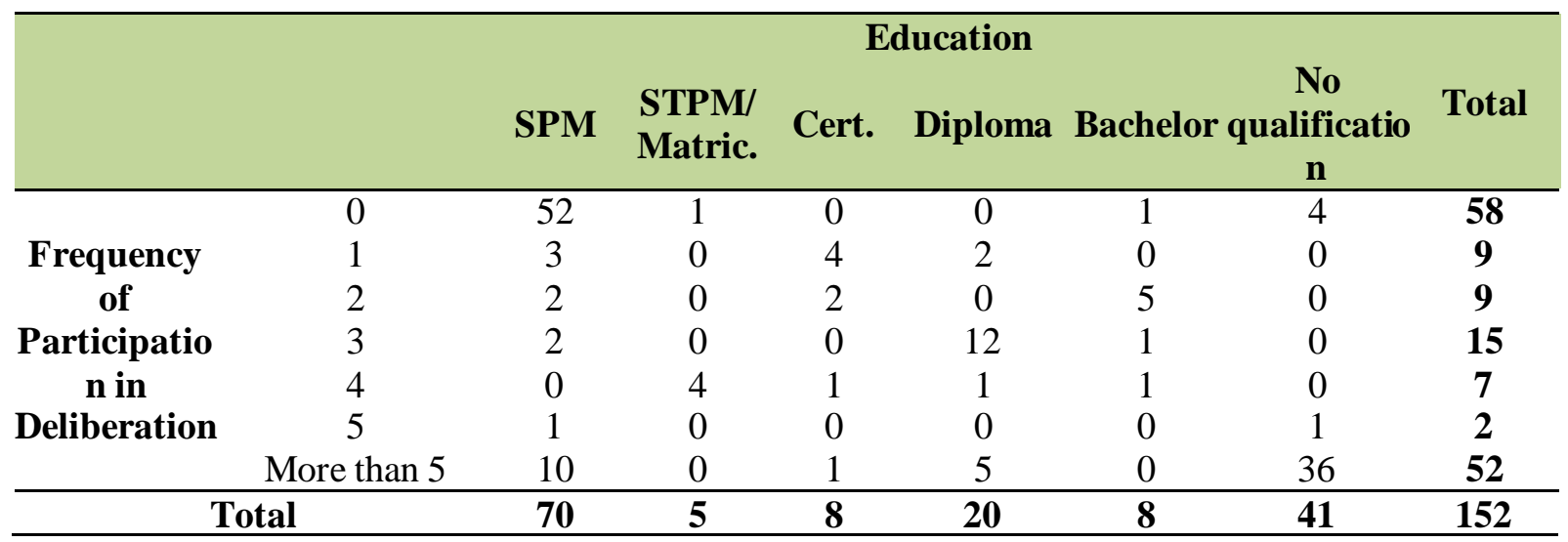

\section{Discussion}

Previous studies have recommended that CBT is an effective tourism approach in eliminating poverty (Croes, 2014). However, based on the socio-demographic analysis above, there are several main findings that can be highlighted. Local community in Kampung Morten can be seen that majority of the respondents did not give opinions towards tourism. Furthermore, majority with SPM qualification have no interest to give opinions in any tourism plans and programs in Melaka. This is most probably of their less exposure and less proficiency in certain tourism strategies and policies. Secondly, most of local community had participated in the deliberation for tourism activities. The findings above indicate that local community of Kampung Morten mostly participate actively in food and beverage, accommodation and transportation. This is because of its strategic location, community have access to involve in tourism businesses, for example trishaw, hawkers in Bandar Hilir as well as homestay business in Kampung Morten.

The study has outlined several recommendations for the study. Firstly, Kampung Morten community should actively engage in the development of tourism by seeking opportunities for partnership with the private sector of developed tourism and perform four management functions, namely, planning, organizing, managing and controlling their respective villages. Through the organization of public meetings of local residents, the use of the local press as a communication tool and surveys of various businesses, residents must be included in key project planning and decision-making activities and be empowered to decide what forms of tourism they want to develop in their respective communities and how the costs and benefits of tourism should be shared among different stakeholders. This would therefore generate job opportunities for local communities, reduce unemployment and raise living standards, and make them much more supportive of the growth of tourism.

Communities should also be encouraged to set up tourism-related associations representing them at the Malaysia Tourism Council (MTC) in Kampung Morten for the successful management of tourism. The researchers also noted that the communities in Kampung Morten do not have adequate knowledge about the benefits of tourism. Local community leaders should play a major role through public forums, seminars and meetings in educating and raising awareness of tourism benefits in their respective villages. In addition, Non-Governmental Organizations (NGO's) should also play a major role in educating local residents about the importance of tourism growth in their respective areas. This will promote higher participation in the growth of tourism. 


\section{Conclusion}

Participation from local community in tourism activities in Kampung Morten is crucial as to promote the identity of Kampung Morten as one of three living heritage sites in Melaka, which are Kampung Morten, Kampung Chetti and Kampung Portugis (Portuguese Settlement). With high commitment of participation from local community, there will be a good impact towards tourism development in Kampung Morten itself. Hence, Kampung Morten will tend to develop as popular tourism destination in Melaka which will gift much more benefits towards local community themselves. To ensure the positive feedback of local community towards participation in tourism activities, there must be several initiatives, strategies and action from state government, local authority and non-governmental organization.

\section{References}

Adofo, S. (2013). Challenges And Coping Strategies Of Student Nursing Mothers In Tertiary Institutions In The Greater Accra Region Of Ghana (M.Phil). University of Ghana.

Ahn, B., Lee, B., \& Shafer, C. S. (2002). Operationalizing sustainability in regional tourism planning: An application of the limits of acceptable change framework. Tourism Management, 23(1), 1-15.

Aliaga, M., \& Gunderson, B. (2000). Introduction to Quantitative research. Doing Quantitative Research in Education with SPSS. Thousand Oaks, CA: Sage Publications, 1-11.

Amir, S., Hakim, L., Nordin, N. E. N., Rosli, N. S., Shokri, N. A. M., Salleh, N. Z. M., ... \& Ramlan, A. A. (2020). Comparison Inventory of UNESCO World Heritage Villages: Kampung Morten, Melaka and Ogimachi Village, Shirakawa-Go, Gifu. Built Environment, 17(2), 21-28.

Armstrong, A. D., Ying, H. J., Malvar, A. S., Mclean, T. M., \& Pestiaux, J. (2003). Community-based Ecotourism. Retrieved April, 15, 2011.

Asker, S., Boronyak, L., Carrard, N., \& Paddon, M. (2010). Effective community based tourism: A best practice manual. Queensland, Australia: Sustainable Tourism Cooperative Research Centre.

Bhuiyan, M. A. H., Siwar, C., Ismail, S. M., \& Islam, R. (2011). The role of home stay for ecotourism development in east coast economic region. American Journal of Applied Sciences, 8(6), 540.

Beaumont, N., \& Dredge, D. (2009). Local tourism governance: A comparison of three network approaches. Journal of Sustainable Tourism, 18(1), 7-28.

Burns, N., \& Grove, S. The practice of nursing research conduct, critique and utilization.

Castro, A. P., \& Nielsen, E. (2001). Indigenous people and co-management: Implications for conflict management. Environmental Science \& Policy, 4(4-5), 229-239.

Choi, H. C., \& Sirakaya, E. (2006). Sustainability indicators for managing community tourism. Tourism Management, 27(6), 1274-1289.

Diedrich, A., \& García-Buades, E. (2009). Local perceptions of tourism as indicators of destination decline. Tourism Management, 30(4), 512-521.

Dredge, D. (2006). Networks, conflict and collaborative communities. Journal of Sustainable Tourism, $14(6), 562-581$.

Gurung, D. B., \& Seeland, K. (2008). Ecotourism in Bhutan: Extending its benefits to rural communities. Annals of Tourism Research, 35(2), 489-508.

Kaul, N.R. (2002): Dynamics of Tourism, Sterling publications New Delhi, p.4.

Kaur, P., Jawaid, A., \& Othman, N. B. A. (2016). The impact of community-based tourism on community development in Sarawak. Procedia-Social and Behavioral Sciences, 2(1), 15-26.

Kennedy, J. 1993. History of Malaya (3rd ed). Kuala Lumpur: S. Abdul Majeed \& Co.

Kontogeorgopoulos, N. (2005). Community-based ecotourism in Phuket and Ao Phangnga, Thailand: Partial victories and bittersweet remedies. Journal of sustainable tourism, 13(1), 4-23.

Leksakundilok, A. (2004). Community participation in ecotourism development in Thailand.

Lee, T. H., Jan, F. H., \& Yang, C. C. (2013). Conceptualizing and measuring environmentally responsible behaviors from the perspective of community-based tourists. Tourism Management, 36, 454-468.

Lepp, A. (2007). Residents' attitudes towards tourism in Bigodi village, Uganda. Tourism Management, 28, 876-885.

Liu, A. (2006). Tourism in rural areas: Kedah, Malaysia. Tourism management, 27(5), 878-889. 
DOI: https://doi.org/10.47405/mjssh.v6i2.673

Marshall, K., White, R., \& Fisher, A. (2007). Conflicts between humans over wildlife management: On the diversity of stakeholder attitudes and implications for conflict management. Biodiversity \& Conservation, 16(11), 3129-3146.

Mosbah, A., \& Saleh, A. A. (2014). A review of tourism development in Malaysia. European Journal of Business and Management, 6(5), 1-9.

Seixas, C., \& Berkes, F. (2009). Community-based enterprises: The significance of partnerships and institutional linkages. International Journal of the Commons, 4(1).

Sheppard, S. R. J., \& Meitner, M. (2005). Using multi-criteria analysis and visualization for sustainable forest management planning with stakeholder groups. Forest Ecology and Management, 207, 171-187.

White, A. T., Ross, M., \& Flores, M. (2000). Benefits and costs of coral reef and wetland management, Olango Island, Philippines. Collected essays on the economics of coral reefs, 215-227.

White, A. T., \& Rosales, R. (2003). Community-oriented marine tourism in the Philippines: role in economic development and conservation. Tourism and development in tropical islands. Political ecology perspectives, 237-262.

Woo, E., Kim, H., \& Uysal, M. (2015). Life satisfaction and support for tourism development. Annals of Tourism Research, 50, 84-97.

Yoon, Y., Gursoy, D., \& Chen, J. S. (2001). Validating a tourism development theory with structural equation modeling. Tourism Management, 22, 363-372. 